\title{
A COMPARATIVE ANALYSIS OF THE PRACTICE OF THE UNITED KINGDOM AND MALAYSIA IN RESPECT OF FREEDOM OF EXPRESSION
}

\author{
Nazli bin Ismail @ Nawang ${ }^{1 *}$ \\ Universiti Sultan Zainal Abidin
}

\begin{abstract}
International law, particularly treaties on human rights, has great influence on the development of the right to freedom of expression. The application of international treaties is very much dependant on the constitutions of individual countries and these constitutions to a large extent are dissimilar from one to another. The position in the United Kingdom is relatively unique since the country has no codified written constitution to safeguard the fundamental right to freedom of expression and as a result it was regarded as residual in nature. Nonetheless, the provisions of the international treaties, particularly the European Convention on the Protection of Human Rights and Fundamental Freedoms (ECHR) have altered this position and accordingly freedom of expression has been formally incorporated into the UK law via the Human Rights Act 1998 (HRA). Meanwhile, the international human rights treaties is considered to have less influence in Malaysia arguably since the country has a written constitution (the Federal Constitution) that contains a specific part on fundamental liberties including the right to freedom of expression.
\end{abstract}

Keywords: International law, treaties, freedom of expression.

\section{Introduction}

The term 'international law' was mentioned for the first time in 1789 by Jeremy Bentham, an English scholar and philosopher, ${ }^{2}$ to refer to 'the mutual transaction between sovereigns as such'. ${ }^{3}$ Since then,

\footnotetext{
Faculty of Law \& International Relations, Universiti Sultan Zainal Abidin (UNISZA)

1 Jeremy Bentham, An Introduction to the Principles of Morals and Legislation. Printed in the Year 1780, and Now First Published. By Jeremy Bentham (London: printed for T. Payne, and Son, 1789), 6.

3 Ibid, 296.
} 
international law, which is also commonly referred to as 'public international law', has traditionally been considered as law that governs rights and obligations between independent states. ${ }^{4}$ This conservative perception is no longer accurate since the subjects ${ }^{5}$ of international law have been extended to include international organisations and to some extent individuals, ${ }^{6}$ even though any individuals could only enforce their rights under international law through action by states. ${ }^{7}$ For that reason, states remain the principal members of the international community ${ }^{8}$ and the discussion on the operation of international law is invariably related to states.

In general, the operation of international law is very much dependent on the constitutional framework of the states. Though no two constitutions are identical, two general theories namely dualism $^{9}$ and monism ${ }^{10}$ have been developed to distinguish approaches adopted by states. ${ }^{11}$ The former regards international law and domestic law as two different systems of law ${ }^{12}$ and thus rights and obligations created by international law do not form part of the domestic law unless they are 'transformed' into domestic law by specific legislation. Whilst the latter considers international law is ipso facto part of domestic law ${ }^{13}$ that can directly be applied by the domestic courts. As to the sources of international law, it is

4 Detailed discussions on the interpretation of the term 'international law, see Mark W Janis, "Individuals as Subjects of International Law," Cornell International Law Journal 17 (1984): 62 -64.

5 The word 'subjects' in this context refers to persons or entities to which international law applies.

6 Lassa Francis Lawrence Oppenheim, Oppenheim's International Law: Volume 1 Peace, ed. Robert Jennings and Arthur Watts, vol. 1, 9th ed. (New York: Oxford University Press, USA, 2008), 16.

7 Anthony Aust, Handbook of International Law (Cambridge: Cambridge University Press, 2005), 13 - 14.

8 Javaid Rehman, International Human Rights Law: A Practical Approach (Harlow: Longman, 2003), 14.

9 Dualism is based on the theory that mind and matter are separate.

10 Monism originates from the theory which denies any duality of mind and matter. Thus, international law and domestic law are not separate.

11 Anthony Aust, Modern Treaty Law and Practice, 2nd ed. (Cambridge: Cambridge University Press, 2007), 181 - 188.

12 Ian Brownlie, Principles of Public International Law, 7th ed. (Oxford: Oxford University Press, 2008), 31 - 33.

13 Abdul Ghafur Hamid, "Judicial Application of International Law in Malaysia: A Critical Analysis," Asia-Pacific Yearbook of International Humanitarian Law Vol. 1 (2005): 196 - 198. 
stipulated in Article 38(1) of the Statute of the International Court of Justice that international customs, international treaties and general principles of law constitute its primary sources. ${ }^{14}$ Nonetheless, since the primary intention of this study is to provide a comparative analysis on the application of international treaties that is specifically related to freedom of expression in the United Kingdom (the UK) and Malaysia, other sources of international law will therefore be intentionally left out and not covered in this paper.

\section{Overview of International Treaties}

A 'treaty' is defined in Article 2(a) of the Vienna Convention on the Law of Treaties (the VCLT) ${ }^{15}$ as:

An international agreement concluded between States in written form and governed by international law, whether embodied in a single instrument or in two or more related instruments and whatever its particular designation.

A treaty is also interpreted as 'a written agreement by which two or more States create or intend to create a relation between themselves operating within the sphere of international law' ${ }^{16}$ Thus, the gist of a treaty is an agreement entered into by two states or more, irrespective of the nomenclature or term used to connote the agreement such as convention, charter, covenant, protocol and many others.

Since a treaty is established upon mutually agreed legal relations between the contracting parties, its provisions and terms shall be enforceable and binding only on those related parties. Non-States parties or third States are not obliged to comply with rights and

14 Article 38(1) of the Statute of the International Court of Justice states that 'The Court, whose function is to decide in accordance with international law such disputes as are submitted to it, shall apply: (a) International conventions, whether general or particular, establishing rules recognised by the contesting States; (b) International custom, as evidence of a general practice accepted as law; (c) The general principles of law recognised by civilised nations; ...'.

15 The VCLT was adopted in Vienna on 22 May 1969 and opened for signature on 23 May 1969 by the United Nations Conference on the Law of Treaties. It has entered into force on 27 January 1980 and as at 28 June 2011, the VCLT has been ratified by 111 States.

16 Arnold Duncan McNair, The Law of Treaties (Oxford: Clarendon Press, 1961), 15. 
obligations of any treaty based on the traditional terminology of pacta tertiis nec nocent nec prosunt. This general rule is now been incorporated in Article 34 of the VCLT which provides that 'a treaty does not create either obligations or rights for a third State without its consent'. However, in certain circumstances it is possible for a treaty to create third-party rights provided that those parties bestow their consent to such treaty. This is clearly stated in Article 36(1) of the VCLT which provides that:

A right arises for a third State from a provision of a treaty if the parties to the treaty intend the provision to accord that right either to the third State, or to a group of States to which it belongs, or to all States, and the third States assents thereto....

Therefore, in the absence of any express consent by the third State, the general rule of non-applicability of the terms of a treaty to nonrelated parties applies.

\section{Application of International Treaties in the United Kingdom}

The uncodified constitution of the UK which confers no special status to international treaties has explicitly demonstrated the status of the country as a dualist state. Any treaties concluded by the Crown shall bind the state in international law but they could not be enforced in the domestic courts. ${ }^{17}$ This has been confirmed by the House of Lords in the case of J.H. Rayner (Mincing Lane) Ltd v Department of Trade and Industry and Others ${ }^{18}$ whereby it was observed that:

...the Crown's power to conclude treaties with other sovereign states was an exercise of the Royal Prerogative, the validity of which could not be challenged in municipal courts; but that the Royal Prerogative did not extend to altering domestic law or rights of individuals without the intervention of Parliament and a treaty was not part of English law unless and until it had been incorporated into it by legislation .... ${ }^{19}$

17 Supra note 10, 189 - 192.

18 [1990] 2 A.C. 418.

19 Ibid, 420. 
The judgment clearly highlights the Crown's prerogative power in making treaties and any unenacted treaties have no legal effects domestically until they are incorporated ${ }^{20}$ into the domestic law. This reflects the fundamental constitutional principles namely the sovereignty of Parliament ${ }^{21}$ and the separation of powers between the Crown, the Parliament and the courts ${ }^{22}$ which had long been rooted and applied in the country since the eighteenth-century. ${ }^{23}$ These doctrines confer the Parliament with the supreme power to enact laws whilst the treaty-making power is exclusively vested with the Crown (in practice the Secretary of State for Foreign and Commonwealth Affairs). ${ }^{24}$ No prior consent of the Parliament is necessary, except for the Ponsonby Rules which require a treaty to be laid before the Parliament with a short explanatory memorandum for 21 days while Parliament is sitting. The significance of this rule is that it ensures the Parliament is informed about the treaty but it does not render the treaty to be part of the domestic law.

The UK has at present ratified five out of nine core international treaties on human rights namely; the International Convention on the Elimination of All Forms of Racial Discrimination (ICERD), the International Covenant on Civil and Political Rights (ICCPR), the International Covenant on Economic, Social and Cultural Rights (ICESCR), the Convention on the Elimination of All Forms of Discrimination against Women (CEDAW) and the Convention Against Torture and Other Cruel Inhuman or Degrading Treatment or Punishment (CAT) ${ }^{25}$ Out of these treaties, the ICCPR ${ }^{26}$ is regarded as the most significant treaty pertaining to the right to freedom of expression as it among others guarantees the fundamental rights of opinion and expression. Article 19(2) of the ICCPR provides that:

20 Incorporation into domestic law can take three forms. For details see supra note 6, 82.

21 Philip Sales and Joanne Clement, "International Law in Domestic Courts: The Developing Framework,” Law Quarterly Review, no. 124 (2008): 389.

22 Supra note 10, 188.

23 Peter Leyland, The Constitution of the United Kingdom: A Contextual Analysis (Oxford: Hart, 2007), 53.

24 Supra note 6, 81.

25 Further details on the list of international treaties ratified by the United Kingdom see http://www.unhchr.ch/tbs/doc.nsf/Statusfrset?OpenFrameSet, (accessed 16 March 2010).

26 ICCPR was approved by the Third Committee of the General Assembly in December 1966 and later came into force in 1976. Further details see supra note 7, 62 - 103. 
Everyone shall have the right to freedom of expression; this right shall include freedom to seek, receive and impart information and ideas of all kinds, regardless of frontiers, either orally, in writing or in print, in the form of art, or through any other media of his choice.

Nonetheless, the provisions of the ICCPR had not been incorporated into the domestic law of the country plainly because identical provisions could be found in the European Convention on the Protection of Human Rights and Fundamental Freedoms (ECHR). In addition, the ECHR had also been ratified earlier in $1951^{27}$ and came into force two years later ${ }^{28}$ compared to the ICCPR which was only ratified on 16 September 1968.

\section{Relation between International Treaties and Freedom of Expression in the United Kingdom}

Freedom of expression is one of the fundamental liberties and an essential characteristic of democratic countries. Its significance has been reiterated in the landmark case of Handyside v. United Kingdom ${ }^{29}$ that the freedom 'constitutes one of the essential foundations of such a society, one of the basic conditions for its progress and for the development of every man' ${ }^{30}$ The importance of this right has been acknowledged and guaranteed at international level by the Universal Declaration of Human Rights (UDHR); international human rights treaties, particularly the ICCPR, as well as by regional human rights regimes namely the ECHR, the American Convention on Human Rights (Pact of San José) and the African Charter on Human and Peoples' Rights (Banjul Charter). ${ }^{31}$ At national level, the right to freedom of expression is safeguarded by various provisions contained in written constitutions and bills of human rights. This right has also received judicial recognition in numerous cases across various jurisdictions.

27 Helen Fenwick and Gavin Phillipson, Media Freedom under the Human Rights Act (Oxford: Oxford University Press, 2006), 1.

28 Geoffrey Robertson and Andrew Nicol, Media Law, 5th ed. (London: Penguin, 2008), 42.

$29(1979-80) 1$ E.H.R.R. 737.

30 Ibid, 754.

31 For detailed discussion on human rights regimes, see Burns $\mathrm{H}$ Weston, Robin Ann Lukes and Kelly M Hnatt, 'Regional Human Rights Regimes: A Comparison and Appraisal', Vanderbilt Journal of Transanational Law, 20 (1987), 585: pp. 592 - 614. 
Several justifications have been submitted for the safeguarding and protecting freedom of expression including the discovery of truth, self-fulfilment, citizen participation in democracy and suspicion of government. ${ }^{32}$ In Regina $v$ Secretary of State for the Home Department, ${ }^{33}$ Lord Steyn observed that freedom of expression could be justified on three grounds namely promoting the self-fulfilment of individuals, discovering the truth through the competition of ideas and serving as lifeblood of democracy. ${ }^{34}$ In relation to democracy, Lord Keith in Derbyshire County Council v Times Newspaper Ltd ${ }^{35}$ ruled that 'it is of the highest importance that a democratically elected government body should be open to uninhibited public criticism'. ${ }^{36}$ Further, in Lingens v. Austria ${ }^{37}$ it was observed that 'freedom of political debate' lies 'at the very core of the concept of a democratic society which prevails throughout the Convention' ${ }^{38}$ Hence, the exercise of this right ought to be realised and safeguarded by countries that adopt democratic systems.

The exercise of the right to freedom of expression in the UK is greatly affected by the provisions of the ECHR. The ECHR was originally developed by the Council of Europe to protect against the revival of repressive dictatorships by ensuring 'the collective enforcement of the rights stated in the UDHR'. ${ }^{39}$ It is argued that the regional human rights regime such as the ECHR holds a greater promise of effectiveness than the universal regime and is expressly encouraged by the United Nations Charter itself. ${ }^{40}$ Perhaps due to this reason, the UK was the first state to ratify the provisions of the ECHR. Unfortunately, the treaty remained unenforceable in the domestic

32 Eric Barendt, Freedom of Speech, 2nd ed. (Oxford: Oxford University Press, 2005), 6 - 23; Kent Greenawalt, "Free Speech Justifications,” Columbia Law Review 89 (1989): 131; Supra note 26, 12 - 19.

33 [2000] 2 A.C. 115

$34 \mathrm{Ibid}, 126$.

35 [1993] A.C. 534

36 Ibid, 547.

37 (1986) 8 E.H.R.R. 407

$38 \mathrm{Ibid}, 419$.

39 Arthur Henry Robertson and John Graham Merrills, Human Rights in the World: An Introduction to the Study of the International Protection of Human Rights, 4th ed. (Manchester, Eng: Manchester University Press, 1996), 120 - 124. 40 Supra, note 30, 588 - 589. 
courts though it was concluded and ratified by the Crown in $1951 .{ }^{41}$ The provisions of the ECHR shall bind the state in international law but they could not be enforced directly in the domestic courts as they had yet to be incorporated into the domestic laws. ${ }^{42}$

Since the ECHR remains unenforceable in the domestic courts, cases of alleged violations of human rights are brought against the government in the European Court of Human Rights (ECtHR) in Strasbourg. Individuals in the country were only permitted to file petition to the ECtHR in $1966{ }^{43}$ and the first successful individual complaint was in the 1975 case of Golder v. United Kingdom ${ }^{44}$ whereby it was ruled that the government was guilty of violating Article 6 and 8 of the ECHR. The first case involving a violation of Article 10 was the case of The Sunday Times $v$. The United Kingdom ${ }^{45}$ in which the UK was found guilty of violating Article 10 when the interference with the applicant newspaper's freedom to publish the thalidomide tragedy was not justified by a 'pressing social need' and therefore could not be considered 'necessary' within clause 2 of Article $10 .{ }^{46}$ Afterwards, there were many cases filed against the UK government and the loss of these cases at Strasbourg is claimed to have led to the incorporation of the ECHR into domestic law via the Human Rights Act 1998 (HRA). ${ }^{47}$

The HRA, which was enacted to give 'further effects to rights and freedoms' ${ }^{48}$ of the ECHR, has greatly changed the landscape of human rights law in the UK. The HRA has incorporated a number of the ECHR articles into its schedule and these provisions are now referred to as the Convention rights. Nonetheless, a few articles namely Articles 1, 13 and 15 are not included within the scope of the

41 Helen Fenwick, Media Freedom under the Human Rights Act (Oxford: Oxford University Press, 2006), p. 1.

42 Supra note 10, 189 - 192.

43 Supra note 27, 42.

44 (1979 - 80) 1 E.H.R.R. 524

45 (1979 - 80) 2 E.H.R.R. 245

46 Ibid, $278-280$.

47 Anthony Aust, "United Kingdom," in The Role of Domestic Courts in Treaty Enforcement: A Comparative Study, ed. David Sloss (Cambridge: Cambridge University Press, 2009), 486.

48 Long title to the HRA. 
Convention rights. ${ }^{49}$ Article 1 is left out simply because the obligation to respect human rights only applies between the contracting states and could not be determined by the local courts. ${ }^{50}$ Similarly, Article 15 which relates with derogation in time of emergency is also an international obligation under the ECHR and could not be reviewed by the domestic courts. ${ }^{51}$ However, Article 13 which provides for the right to an effective remedy is arguably omitted to avoid confusion with sections 7, 8 and 9 of the HRA that are specifically formulated to lay down the remedial structure in the UK. ${ }^{52}$

Prior to the coming into force of the HRA, any issues relating to freedom of expression were addressed by the judges with reference to the common law principles since the country does not have any codified written constitution. In the case of $A G v$. Guardian Newspaper Ltd (No. 2), ${ }^{53}$ Lord Goff stated that 'freedom of expression has existed in this country perhaps as long, if not longer, than it has existed in the world', ${ }^{54}$ indicating that freedom of expression has long been recognised in the country's legal system. However, it was argued that the absence of express provisions on freedom of expression rendered such right residual in nature since its exercise was subject to any restrictions imposed by the law. ${ }^{55}$ This position has been reaffirmed by Lord Donaldson in the same case that 'the starting point of our domestic law is that citizen has a right to do what he likes, unless restrained by the common law or statute' ${ }^{56}$ Nevertheless, the ECHR principles have already left a significant impact on the UK domestic law and have been applied; either indirectly through judgments against the UK government by the ECtHR in Strasbourg, or directly through the use of legal

49 Section 1(1) provides that the phrase 'Convention rights' to cover 'Articles 2 to 12 and 14 of the Convention, Articles 1 to 3 of the First Protocol, and Articles 1 and 2 of the Sixth Protocol, as read with Articles 16 to 18 of the Convention'.

50 Alastair N Brown, Human Rights Act 1998, Greens annotated acts (Edinburgh: W.Green, 2003), 4 - 5.

51 Ibid.

52 Human Rights Act 1998, 2nd ed., Current Law Statutes Annotated Reprints (London: Sweet \& Maxwell, 1998), 42-8.

53 [1990] 1 AC 109.

54 Ibid. 283.

55 Supra note 31, 40.

56 Supra note 52, 178. 
arguments based on the ECHR in the domestic courts. ${ }^{57}$ However, these provisions could only be considered by the courts as the last resort especially in cases where there was ambiguity in the statute affecting the Convention rights or when the courts were uncertain on the application of any point of the common law. ${ }^{58}$

The situation is reversed post the HRA era as courts in the UK are required to consider relevant Strasbourg jurisprudence when determining any issues related with the Convention rights. ${ }^{59}$ Further, the HRA creates an important obligation on the courts to interpret all primary and subsidiary legislation (past or future) wherever possible to be in compliance with the Convention rights. ${ }^{60}$ The HRA also mandates all public authorities including the courts to act compatibly with the Convention rights unless they are forbidden from doing so by primary or secondary legislation. ${ }^{61}$ Further, it also enables a person who claims to be a 'victim' of the public authority to commence legal proceedings in any relevant domestic court or tribunal to enforce his rights. ${ }^{62}$ Any person who is not a victim and cannot initiate legal actions under section 7 may still rely on the court's obligation to interpret legislation compatibly with the Convention rights. Thus, the incorporation of the provisions of the ECHR into the domestic laws has established a positive milieu for the operation of the freedom of expression in the UK.

\section{The Right to Freedom of Expression in the United Kingdom}

Article 10 of the ECHR, which is incorporated as appendixes in the HRA, adopted almost word by word of Article $19^{63}$ of the UDHR. ${ }^{64}$ The article confers the right to freedom of expression on

57 Blackstone's Guide to the Human Rights Act 1998, 4th ed. (London: Blackstone, 2007), 4 - 5.

58 Supra note 51, 42 - 43.

59 Section 2 of the HRA.

60 Section 3(1) of the HRA.

61 Section 6 of the HRA.

62 Section 7 of the HRA.

63 Article 19 provides that 'Everyone has the right to freedom of opinion and expression; this right includes freedom to hold opinions without interference and to seek, receive and impart information and ideas though any media and regardless of frontiers'.

64 The UDHR is a non-binding declaration and was adopted by the United Nations in 1948 as part of the International Bill of Human Rights. 
all individuals in the Member States including the UK. Paragraph 1 of the said article provides:

Everyone has the right to freedom of expression. This right includes the freedom to hold opinions and to receive and impart information and ideas without interference by a public authority and regardless of frontiers. This article shall not prevent States from requiring the licensing of broadcasting, television or cinema enterprise.

Thus, paragraph 1 clearly provides the scope of such right to include freedom to hold opinions, freedom to impart information and ideas and freedom to receive information and ideas. These freedoms shall be enjoyed free from any interference by public authorities and irrespective of the medium by which the expression is communicated. However, the exercise of freedom of expression is subject to certain restrictions as per stated in paragraph 2 of the same article. Paragraph 2 states that:

The exercise of these freedoms, since it carries with it duties and responsibilities, may be subject to such formalities, conditions, restrictions or penalties as are prescribed by law and are necessary in a democratic society, in the interest of national security, territorial integrity or public safety, for the prevention of disorder or crime, for the protection of health or morals, for the protection of the reputation or rights of others, for preventing the disclosure of information received in confidence or for maintaining the authority and impartiality of the judiciary.

Thus, the right to freedom of expression is not absolute and can be restricted on seven grounds set out in paragraph 2 . There are numerous cases that highlight the restrictions imposed by the UK government. The first major case that occurred after the enactment of the HRA is the case of $R \mathrm{v}$ Shayler ${ }^{65}$ In this case, the House of Lords had to determine whether the ban imposed by the Official Secrets Act 1998 was disproportionate to protect the national security and

65 [2003] 1 A.C. 247. 
therefore incompatible with the HRA that grants the right to freedom of expression. By referring to the relevant ECtHR rulings, it was held that the restrictions to the free speech were not disproportionate as the ban was not absolute but was merely confined to disclosure without lawful authority.

It is important to emphasise that the restrictions may only be imposed subject to limitations 'prescribed by law' and 'necessary in a democratic society' under paragraph 2 of Article 10. Apart from that, section 12 of the HRA accords more protection to this right by preventing injunctions being granted ex parte by the courts unless all practicable steps to notify the person against whom such injunctions to be made or there are compelling reasons why he should not be notified. Further, the courts are required to look at the merits of the case before granting any relief. Thus, this requirement makes interim restraints more difficult in cases where the right to freedom of expression is at issue. For example according to section 12 (4) of the HRA the court is required to have 'particular regard' to the right to freedom of expression where the proceedings relate to material which the respondent claims, or which appears to the court, to be journalistic, literary or artistic material. In such case, the court must have regard to the extent to which the material has, or is about to, become available to the public, or it is, or would be, in the public interest for the material to be published. Nonetheless, this section does not render freedom of expression to be an absolute right nor place greater weight to such freedom compared to other competing Convention rights such as the right to privacy. It merely grants discretion to the court to lean in favour of freedom of expression within the margin of appreciation enjoyed under the convention. ${ }^{66}$ To sum up, it is submitted that the right to freedom of expression is now clearly spelt out in the HRA but the exercise of such right is not absolute as it is subjected to certain restrictions and limitations.

\section{Application of International Treaties in Malaysia}

Prior to the Merdeka Day, ${ }^{67}$ the courts in Malaysia (Federation of Malaya) had adopted a similar approach to that practised by the British courts namely the doctrine of transformation for treaties and the doctrine of incorporation with certain limitations for customary

66 Supra note 51, 42 - 25.

6731 August 1957. 
international law. ${ }^{68}$ Post Merdeka Day, the operation of any law (either municipal or international) is made subject to the express provisions of the Federal Constitution (the FC). Article 4(1) of the FC provides that:

This Constitution is the supreme law of the Federation and any law passed after Merdeka Day which is inconsistent with this Constitution shall, to the extent of the inconsistency, be void.

This provision upholds the notion of constitutional supremacy in the Malaysian legal system as it expressly stipulates that the FC shall be the highest law of the land and any laws shall be declared void if they are in conflict with any provisions of the FC. The status of the FC has also been observed by Tun Suffian LP in the case of Ah Thian v. Government of Malaysia ${ }^{69}$ that the doctrine of Parliamentary supremacy does not apply in Malaysia as the FC is the highest law of the country and it can lawfully restrict the power of the Parliament to make law. Nonetheless, a close scrutiny of the aforesaid provision reveals that the law is silent on the status of international law (either international treaty law or customary international law). Further, there are no specific provisions in the FC that deal with the application of international law. Thus, reference must be made to general provisions and decided cases that may lend some assistance on this matter.

Article 39 of the FC which outlines the executive authority in Malaysia provides that:

The executive authority of the Federation shall be vested in the Yang di-Pertuan Agong and exercisable ... by him or by the Cabinet or any Minister authorised by the Cabinet....

Further, Article 80(1) states that:

...the executive authority of the Federation extends to all matters with respect to which Parliament may make laws....

68 Supra note 12, 197.

69 [1976] 2 MLJ 112. 
The power of the Parliament to enact laws is stated in Article 74(1) of the FC whereby it stipulates that:

...Parliament may make laws with respect to any of the matters enumerated in the Federal List ${ }^{70}$ or the Concurrent List ${ }^{71} . . . "$ The Federal List among others covers 'external affairs, including (a) treaties, agreements and conventions with other countries and all matters which bring the Federation into relations with other countries; (b) implementation of treaties, agreements and conventions with other countries; ....

Thus, the aforesaid provisions prove that the power to conclude international treaties, agreements and conventions is exclusively reserved to the executive authority of the country (i.e. the YDPA) and could only be exercised by the YDPA himself or any authorised Minister of the Malaysian Government. The Parliament, as the law making body in the country, is only entrusted to implement the treaties and incorporate them into domestic laws so that they are enforceable in the domestic courts.

This position is clearly illustrated by the judgment of Thomson CJ in the case of The Government of the State of Kelantan v. The Government of the Federation of Malaya and Tunku Abdul Rahman Putra Al-Haj.72 In this case, the state government of Kelantan has commenced proceedings against the Federal Government and Tunku Abdul Rahman arguing that the Malaysia Agreement, an international treaty which was signed on $9^{\text {th }}$ July 1965 by the Federation of Malaya, the United Kingdom, Singapore, Sarawak and North Borneo (Sabah) was null and void on the ground that the consent of the individual states in the Federation of Malaya had not been formally procured before the conclusion of the agreement. It was held that by referring to Articles 39 and 80(1) of the FC, the Malaysia Agreement was not a nullity as the power to conclude the agreement was lawfully exercised by the body that was conferred express authority by all of the states in the Federation. As Thomson CJ said:

70 Federal List means the First List of the Ninth Schedule - Article 160(2) of the FC.

71 Concurrent List means the Third List of the Ninth Schedule - Article 160(2) of the FC.

72 [1963] 1 MLJ 355. 
The Malaysia Agreement is signed for the Federation of Malaya by the Prime Minister, the Deputy Prime Minister and four other members of the Cabinet. There is nothing whatsoever in the Constitution requiring consultation with any State Government or the Ruler of any State. ${ }^{73}$

This decision clearly espoused the principle that the treaty-making capacity is exclusively entrusted by the FC to the Executive or the Cabinet. ${ }^{74}$ Since any treaties would only be enforceable domestically upon the passing off necessary laws by the Parliament, the Malaysia Act 1963 was enacted on 16 September 1963 subsequent to the signing of the Malaysia Agreement. There are a few other statutes that have been passed by the Parliament to give legal effects to international treaties that have been ratified by Malaysia including the Geneva Conventions Act 1962, the Diplomatic Privileges (Vienna Convention) Act 1966, the International Organisations (Privileges and Immunities) Act 1992, the Consular Relations (Privileges and Immunities) Act 1999 and many others. ${ }^{75}$ On the other hand, it is argued that there are treaties that can be implemented and enforced without the necessity of enacting any relevant legislation. ${ }^{76} \mathrm{~A}$ good illustration would be the Treaty of Friendship between the Malaysia and Indonesia which was signed on 10 April 1959 and has resulted in several cultural exchanges being implemented between the neighbouring countries without specific legislation. ${ }^{77}$ Nonetheless, in general international treaties that have significant impact on the rights of individuals in the country or involve major changes in municipal law would definitely require relevant statutes to be passed by the Parliament to be legally enforceable in the local courts.

73 Ibid, 359

74 Abdul Ghafur Hamid, "Treaty-Making Power in Federal States with Special Reference to the Malaysian Position,” Journal of Malaysian and Comparative Law Vol. 30 (2003): 80 - 82.

75 Supra note 12.

76 Heliliah Haji Yusof, “Internal Application of International Law in Malaysia and Singapore,” Singapore Law Review 1 (1969): 65.

77 Ibid. 


\section{Relation between International Treaties and Freedom of Expression in Malaysia}

At present, Malaysia has only ratified two international treaties on human rights namely CEDAW and CRC. ${ }^{78}$ Both of these treaties were acceded to in 1995 with certain reservations on the basis of religious and national or cultural relativism. ${ }^{79}$ The country has also signed, though not ratified, ${ }^{80} \mathrm{CRPD}^{81}$ but unfortunately, the ICCPR which safeguards fundamental human rights including the right to freedom of expression has yet to be signed. The Malaysian government has been urged by the Human Rights Commission of Malaysia (SUHAKAM) to ratify certain core treaties including the ICCPR but so far the situation remains the same. Arguably it is claimed that special protection accorded to the Bumiputera as well as the persistent use of several legislations which contravenes the fundamental liberties are among the key factors for such resistance. ${ }^{82}$ The non-accession of the ICCPR is further intensified with the absence of regional arrangements that ought to safeguard the fundamental rights of the people in Asia or Asia-Pacific. ${ }^{83}$ The significance of establishing a regional human rights regime comparable to the ECHR in Europe, Pact of San José in America or Banjul Charter in Africa has been explicitly stressed by the Vienna Declaration and Programme of Action (the VDPA). ${ }^{84}$ Article 37 of the VDPA stipulates that:

Regional arrangements play a fundamental role in promoting and protecting human rights. They should reinforce universal human rights standards, as

78 CRC was acceded on $17^{\text {th }}$ February 1995 whilst CEDAW was on $5^{\text {th }}$ July 1995. For details see Malaysia's status at http://www.unhchr.ch/tbs/doc.nsf/ Statusfrset?OpenFrameSet, (accessed 16 March 2010).

79 Jaclyn Ling-Chien Neo, "Malaysia’s First Report to the CEDAW Committee: A Landmark Event for Women's Rights in Malaysia," Asian Yearbook of International Law 13 (2007): 303.

80 CRPD was signed on $8^{\text {th }}$ April 2008.

81 Elizabeth Looi and Shanon Shah, Human Rights: What's Stopping Malaysia? (The Nut Graph, December 10, 2008), http://www.thenutgraph.com/print/1226, (accessed March 17, 2010).

82 Ibid.

83 Ralph Wilde, “NGO Proposals for an Asia-Pacific Human Rights System,” Yale Human Rights \& Development Law Journal 1 (1998): 137.

84 The VDPA is a human rights declaration adopted by consensus at the World Conference on Human Rights on 25 June 1993 in Vienna, Austria. 
contained in international human rights instruments, and their protection ... The World Conference on Human Rights reiterates the need to consider the possibility of establishing regional and sub-regional arrangements for the promotion and protection of human rights where they do not already exist.

In line with the aforesaid provision, several proposals and recommendations have been put forward by various parties in realising the establishment of such regime for the Asian region. Unfortunately, until a concrete resolution and mutual agreement could be reached between leaders of the Asian countries, it is very much unlikely to see such regime to be translated into a reality in the near future.

Regardless of the non-application of the ICCPR and the lack of regional human rights regime for Asia, the right to freedom of expression is principally accorded to all citizens in Malaysia. The right to freedom of expression together with other fundamental rights are clearly provided in Part II of the FC (Articles 5 - 13) under the heading of 'Fundamental Liberties'. These provisions are specifically arranged after the supremacy clause of the FC in Article 4 and by virtue of this setting, it appears that the exercise of freedom of expression and other basic human rights is very well guarded and constitutionally bestowed upon all of the Malaysian citizens. Hence, it can be concluded that the international treaties on human rights have no significant impact on the right to freedom of expression in Malaysia since such right has been exclusively included in the provision of the Constitution itself.

\section{The Right to Freedom of Expression in Malaysia}

The right to freedom of expression is explicitly stated in Article 10(1) of the FC which provides that:

Subject to Clauses (2), (3) and (4) - (a) every citizen has the right to freedom of speech and expression.

Plain reading of this article shows that such right is guaranteed to the Malaysian citizens only and non-citizens are not entitled to this freedom, though other rights such as freedom of religion and right 
to property are made available to them. ${ }^{85}$ The right to freedom of expression is not exclusively reserved to political speech only ${ }^{86}$ as commercial and artistic expressions are also protected by the law though they receive less attention from the public. As to the level of protection between these three classes of speech, it is unclear whether the situation in Malaysia would be similar to the UK, which accord highest protection to the political speech compared to other types of speech. ${ }^{87}$ As such, in the absence of any express provisions and decided cases, it is submitted that there would be no different treatment between these categories of expression.

In the opening sentence of the aforesaid article, the exercise of this right is straight away subjected to various limitations in clauses 2, 3 and $4 .^{88}$ Clause 2 to Article 10 reads:

Parliament may by law impose -

(a) on the rights conferred by paragraph (a) of Clause (1), such restrictions as it deems necessary or expedient in the interest of the security of the Federation or any part thereof, friendly relations with other countries, public order or morality and restrictions designed to protect the privileges of Parliament or of any Legislative Assembly or to provide against contempt of court, defamation, or incitement to any offence.

85 Shad Saleem Faruqi, "Human Rights and the Constitution,” in Human Rights and the National Commission, ed. S. Sothi Rachagan and Ramdas Tikamdas (HAKAM, 1999), 140.

86 The House of Lords in Reynolds v. Times Newspaper Ltd [2001] 2 A.C. 127 at page 175 confined political speech only to 'statements made about the actions and qualities of those currently or formerly elected to Parliament and those with immediate aspirations to be members, so far as those actions and qualities directly affected their capacity ... to meet their public responsibilities'.

87 In the leading case of Lingens v. Austria (1986) 8 E.H.R.R. 407, it was ruled that political speech is the core of a democratic society that should be given more protection by the courts. This ruling has been followed by the English courts in other cases including Regina v. Secretary of State for the Home Department [2000] 2 A.C. 115 and Reynolds v. Times Newspaper Ltd [2001] 2 A.C. 127.

88 Clause 3 is not related with freedom of expression because it restricts the right to form associations under Article 10(1)(c) of the Constitution. 
Thus, clause (2) endows the Parliament with eight grounds to restrict the exercise of such right. Further, clause 4 of the same article adds up another four limitations on freedom of expression. This clause reads:

\begin{abstract}
In imposing restrictions in the interest of the security of the Federation or any part thereof or public order under Clause (2)(a), Parliament may pass law prohibiting the questioning of any matter, right, status, position, privilege, sovereignty or prerogative established or protected by the provisions of Part III, Article 152,153 or 181 otherwise than in relation to the implementation thereof as may be specified in such law.
\end{abstract}

It is essential to note here that clause 4 was introduced subsequent to the constitutional amendment in 1971. The amendment was passed following the race riots in several parts of the country in $1969 .{ }^{89}$ As a result, the Parliament has been entrusted with more legislative power to further restrain freedom of expression on matters which are considered to be politically sensitive in Malaysia. They are the right to citizenship in Part III of the FC, the status of the Malay language in Article 152, the position and privileges of the Malays and the natives of Sabah and Sarawak in Article 153 and the prerogatives of the Malay Sultans and the Ruling Chiefs of Negeri Sembilan in Article 181.

For this reason, it has been observed that the article is remarkable for what it takes away rather than what it gives. ${ }^{90}$ Article 10 of the FC can be regarded as the most repressive provision as it provides abundant restrictions on freedom of expression. The provision of Article 10 has also been discussed in the case of Lau Dak Kee v. Public Prosecutor. ${ }^{91}$ It was ruled by Mohamed Azmi J that:

Article 10(1) of the Federal Constitution guarantees the rights of every citizen to freedom of speech, assembly and association. These rights are, however, subject to any law passed by Parliament. ${ }^{92}$

89 Andrew Harding, Law, Government and the Constitution in Malaysia (The Hague: Kluwer Law International, 1996), 42 - 45.

90 Ibid, 169.

91 [1976] 2 MLJ 229.

92 Ibid p. 230. 
Apart from Article 10, the Parliament is also authorised by Article 149 to pass legislative action to fight subversion whilst Article 150 permits the Parliament to enact statutes to combat an emergency. Altogether there are fourteen massively broad grounds available for the Parliament to legally confine the exercise of this right. Hence, it is submitted that the existence of these restrictions has a great impact on democracy in Malaysia as it has rendered the exercise of freedom of expression at the mercy of Parliament. ${ }^{93}$

The rationale for having these restrictions has been aptly described by Raja Azlan Shah J in PP v. Ooi Kee Saik \& $\mathrm{Ors}^{94}$ who quoted the following passage from A.K. Gopalan v. State of Madras ${ }^{95}$ with approval:

There cannot be any such thing as absolute or uncontrolled liberty wholly free from restraint; for that would lead to anarchy and disorder. The possession and enjoyment of all rights ... are subject to such reasonable conditions as may be deemed to be ... essential to the safety, health, peace and general order and morals of the community ... What the Constitution attempts to do in declaring the rights of the people is to strike a balance between individual liberty and social control. ${ }^{96}$

This judgment emphasised on the significance of imposing certain limitations since unbridled freedom might be misused as an instrument of mischief. In fact, most democratic countries in the world such as the UK and even the US, which accords strong protection to free speech in the First Amendment to the US Constitution, ${ }^{97}$ have devised certain limitations to this right most notably child pornography and obscenity laws which aim to protect

93 Shad Saleem Faruqi, “The All-Powerful Executive”, October 1, 2005, 2, http:// www.sun2surf.com/articlePrint.cfm?id=11381, (accessed August 23, 2010).

94 [1971] 2 MLJ 108

95 AIR [1950] SC 27

96 Ibid p. 111.

97 Amendment I of the United States Constitution provides that: "Congress shall make no law respecting an establishment of religion, or prohibiting the free exercise thereof; or abridging the freedom of speech, or of the press; or the right of the people peaceably to assemble, and to petition the Government for a redress of grievances". 
the broader interest of the community. Undoubtedly, the extent and necessity of restrictions on freedom of expression in Malaysia are different from other countries due to the local circumstances and political experiences in the past.

Nonetheless, the Parliament's assessment of the necessity or expediency of any of these limitations is not open for challenge. ${ }^{98}$ The only possible recourse is through an application to declare that such law is unconstitutional on the ground that it falls outside the scope specified by the Constitution. This point has also been addressed by Chang Min Tat J in Madhavan Nair v. Public Prosecutor that:

Any condition limiting the exercise of the fundamental right to freedom of speech not failing within the four corners of Article 10 clauses (2), (3) and (4) of the Federal Constitution cannot be valid.

This judgment signified that the validity of such a law limiting freedom of expression could be challenged in the court of law. Unfortunately, although there have been nine challenges ${ }^{99}$ against the validity of laws passed by the Parliament after independence, so far there is not a single law that has been declared unconstitutional by the court. ${ }^{100}$ Due to these reasons, it is feared that the legislative power conferred on the Parliament is open to abuse by the government to maintain its political power. ${ }^{101}$ Due to this reason,

98 Article 4(2)(b) of the Constitution provides that "The validity of any law shall not be questioned on the ground that - it imposes such restrictions as are mentioned in Article 10(2) but those restrictions were not deemed necessary or expedient by Parliament for the purpose mentioned in that Article".

99 The cases are City Council of George Town v. Government of Penang [1967] 1 MLJ 169; Selangor Pilots Association v. Government of Malaysia [1975] 2 MLJ 66; PP v. Datuk Haji Harun [1977] 1 MLJ 180; Teh Cheng Poh v. PP [1979] 1 MLJ 50; Malaysian Bar v. Government of Malaysia [1986] 2 MLJ 225; Menon v. Government of Malaysia [1987] 2 MLJ 642; PP v. Dato' Yap Peng [1987] 2 MLJ 311; Mamat bin Daud v. Government of Malaysia [1988] 1 MLJ 119; Haji Nordin Salleh \& Haji Wan Mohamed Najib Wan Mohamed v. Dewan Undangan Negeri Kelantan [1992] 1 MLJ 143.

100 Abdul Aziz Bari and Farid Sufian Shuaib, Constitution of Malaysia: Text and Commentary (Petaling Jaya: Prentice Hall, 2004), 34.

101Abdul Aziz Bari, Malaysian Constitution: A Critical Introduction (Kuala Lumpur: Other Press, 2003), 153 - 156. 
some scholars claimed that the right to freedom of expression in this country is residual in nature ${ }^{102}$ since it can paradoxically, only be exercised subject to various restrictions imposed by other laws.

\section{Conclusion}

International human rights treaties have considerable effects on the exercise of the right to freedom of expression in the UK. Such right has now been formally incorporated into the HRA and undoubtedly it should no longer be viewed as residual in nature. Nonetheless, freedom of expression is not an absolute right and its implementation may be restricted by certain limitations so long as they are 'prescribed by law' and 'necessary in a democratic society'. On the other hand, international treaties on human rights have less significant impact in Malaysia. Arguably, it is submitted that the Malaysian FC has expressly contained a specific chapter on fundamental liberties including Article which clearly guarantees the right to freedom of expression to all citizens. Nonetheless, the exercise of this right is highly controversial since it is made subjected to numerous statutory constraints passed by the Parliament and challenges on the validity of these statutes has yet to claim any success. Thus, it is submitted that the legal position is still unclear whether the right to freedom of expression is really exercisable in its true sense in this country.

102 Supra note 99, 33. 